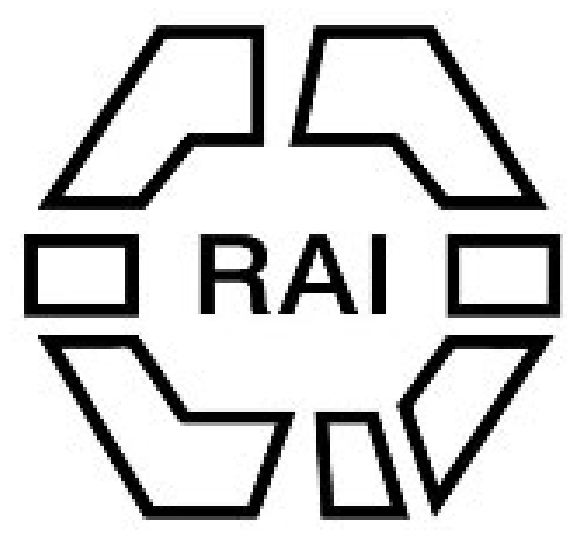

Presidential Address. The Influence of Environment on Man.

Author(s): William Ridgeway

Source: The Journal of the Royal Anthropological Institute of Great Britain and Ireland, Vol. 40 (Jan. - Jun., 1910), pp. 10-22

Published by: Royal Anthropological Institute of Great Britain and Ireland

Stable URL: http://www.jstor.org/stable/2843141

Accessed: 25/06/2014 05:34

Your use of the JSTOR archive indicates your acceptance of the Terms \& Conditions of Use, available at http://www.jstor.org/page/info/about/policies/terms.jsp

JSTOR is a not-for-profit service that helps scholars, researchers, and students discover, use, and build upon a wide range of content in a trusted digital archive. We use information technology and tools to increase productivity and facilitate new forms of scholarship. For more information about JSTOR, please contact support@jstor.org. 


\section{PRESIDENTIAL ADDRESS.}

\section{THE INFLUENCE OF ENVIRONMENT ON MAN.}

\section{By Professor William Ridgeway, Sc.D., F.B.A., Hon. LL.D., Hon. Litr.D.}

In this my concluding address, my first and most pleasing duty is to offer my heartiest thanks to the Officers and Council for their unfailing kindness and consideration for my shortcomings and for their unflagging loyalty during my two years of office. Indeed, had I not known beforehand the remarkable qualities of the Secretary, Treasurer, and Assistant Secretary, I would not have undertaken the responsibility of presiding over the Institute.

It may not be out of place to review briefly the progress made by the Institute during the last two years. The story, I rejoice to say, is one of continued prosperity and progress, alike in point of numbers and financial stability. The sum of one thousand pounds, bequeathed to us by the late Miss Wolfe, has not only given us a substantial nucleus for a reserve and special grant fund, but it indicates that the general public are awaking to the great importance of Anthropology. My optimism is confirmed by the large donations as well as by the legacy of five thousand pounds recently received by Cambridge for the erection of a new Anthropological Museum.

In view of these symptoms of a growing interest in our special science we must not regret the expenditure incurred in promoting the proposal for the establishment of an Imperial Bureau of Anthropology within this Institute, the main part of our outlay having been incurred in an effort to obtain the modest grant of five hundred pounds per annum from the Chancellor of the Exchequer. Though we have failed in our first attempt upon the coffers of the Treasury, as has been the almost universal experience of those who later on have succeeded in their demand, we must not consider that our efforts have been wholly barren. The circulation of our memorial, to which were appended the signatures of a long array of the most distinguished Indian and Colonial administrators, had the allimportant result of eliciting the public enunciation from the Prime Minister that the time had now come when a knowledge of Anthropology "must form part of the normal equipment of those who in the Consular, Indian, and Colonial services, have to carry on the work of the Empire, especially in its outlying parts." But this was not all. The reception of our deputation by the Prime 
Minister brought under the notice of many other Ministers, ex-Ministers, and great officials, the fact that Anthropology must now be regarded as an applied science, and that henceforward it must be recognised as an important instrument. for carrying on the business of the State. Nor did the effect produced by our memorial end eyen here. The demonstration of the practical utility of Anthropology not only for administrative but also for commercial purposes and the fact that many leading shipowners, manufacturers, and traders had endorsed our opinion, caught hold upon the great business centres of the kingdom. All the leading newspapers in Liverpool, Manchester, and Birmingham took up the matter seriously and warmly, and not only did they publish long and important articles on our project and our deputation at the time, but have continued to refer to our doctrines at various intervals since. In India and in the Crown Colonies the greatest interest in our effort was and is being taken by leading administrators. I need give you no better proof of this than when I tell you that last year the Government of India recommended an annual grant of one hundred pounds for five years to the Institute for the purpose of our proposed Bureau, and that the Government of British East Africa made a recommendation of fifty pounds per annum for the same purpose. I regret to say that Lord Morley in the one case, and Lord Crewe in the other, did not sanction the recommendations of the officials engaged in the active work of administration, and who are best qualified to judge of the pràctical needs of their subordinates.

The facts which I have briefly sketched all point to the conclusion that what we now want is to continue steadfast in our determination to accomplish our end, and on every opportunity to bring influence to bear on the Ministers of the Crown. This of course must be carried on principally through members of Parliament, and here I must express our deep obligations to those members on both sides of the House of Commons, Sir W. Anson, Mr. S. H. Butcher, Mr. Annan Bryce, and Mr. Russell Rea, for their generous aid in furthering the object of our memorial. Mr. Rea has especial claims upon our gratitude, for he not only made all the arrangements with the Prime Minister for the reception of our deputation, but continued afterwards to make further efforts to extract a grant from the Chancellor of the Exchequer. All of us, no matter what our politics may be, sincerely regret. that a man like Mr. Rea, with broad and enlightened views, should have lost his seat at the recent elections. Personally I hope before long he may find another constituency. It is the duty of every Fellow of the Institute to bring all the influence that he or she can to bear upon officials and especially on members of Parliament, for it is only by the exertion of pressure upon the Treasury of men with votes that we hope ultimately to obtain our grant. Ministers are just as susceptible to the influence of environment as everything else in Nature, and it must be our duty to see that their environment shall be made as healthy as. possible. The action of a proper environment upon Ministers of the Crown naturally leads me to the general question of the influence of Environment on Man in general. 
In my address to the Anthropology section of the British Association in 1908, I attempted to show that many of the chief errors which impede the scientific study of man, which lead to the maladministration of alien races, and which beget blunders of the gravest issue in our own social legislation, are due in no small degree to man's pride in shutting his eyes to the fact that he is controlled by the same laws as the rest of the animal kingdom. My arguments excited considerable discussion both at the time and since in this country, on the Continent and in America, but only one systematic attempt to refute my doctrines has been attempted. I refer to an article by Mr. Bernard Houghton, of the Indian Civil Service, in Science Progress for October, 1909. To-night I intend only to deal with one of the three aspects of which I treated at the British Association, and to confine myself to inquiring how far the physical side of Man is liable to modification by his environment. With the criticisms of Mr. Houghton on the other aspects of my address I will deal in Science Progress. ${ }^{1}$ By environment, as I carefully explained in my address at the British Association, I mean all the conditions under which men live and which of course vary widely on different parts of the globe.

Foremost in importance amongst the problems relating to Man now being discussed by physical anthropologists, is the stratification of populations in Europe. It had generally been held before I wrote, as an article of faith, that Europe was first peopled by a non-Aryan race. Of course it is difficult for us to say what were the physical characteristics of Palæolithic Man, for apart from a certain number of skulls our evidence concerning him is entirely confined to his implements of flint found in the river gravels, caves and high plateaux.

But when we come to Neolithic Man the problem becomes less hopeless. It had been generally held that the first Neolithic men in Europe, whether they were descended or not from their Palæolithic predecessors, had long skulls, but were not Aryans; that later on came a migration of short-skulled people from Asia who passed along Central Europe into France, becoming what is commonly termed the Alpine, by some the Ligurian, by others the Celtic race. Later these two primitive non-Aryan races are supposed to have been overrun by the Aryans, who, when these theories were first started, were universally considered to have come from the Hindu Kush, but are now generally believed to have originated in Upper Central Europe. The Aryans are generally assumed to have had a blonde complexion.

In my Early Age of Greece, I had refused to regard the short-skulled Alpine race as differing materially from the dark long-headed melanochrous race found in Italy, Greece and Spain, and on the other hand from the blonde race of Northern Europe. At the York Meeting of the British Association in 1906, I urged that the Alpine race was in no sense Mongoloid and that its short skull was due to modification along the Alps. In other words, that the brachycephalic European race was of European, and not of Asiatic origin.

1 This article has now appeared in Science Progress (July, 1910). 
This view was later on supported by Professor W. Wright in the Hunterian Lectures, whilst it was strongly expressed by Professor Gustav Retzius in this very place when he delivered a few weeks ago his Huxley Memorial lecture. I may further add that in the recent publication of the Danish Anthropological Committee Dr. Soren Hansen has drawn the conclusion from the very complete data furnished by the Anthropological Survey of Denmark that the old doctrine with which the Danish investigators started that the population of Denmark consisted of two distinct elements (1) a tall blonde race with long skull, and (2) a short dark race with short skull-must be rejected. The evidence points rather to a shading off from the dark short type into the tall blonde type.

In my address I maintained, as also in a monograph ("Who were the Romans?" British Academy, 1907) published some time earlier, that the blonde tall race of Upper Europe was identical in origin with that small dark long-headed race of the three southern peninsulas of Europe, generally included up to then under the name of "Mediterranean Race" with the Hamites of North Africa and the Semites of South-western Asia.

My argument was, and is, that as the ice-sheet receded Man passed upwards. from the south or south-east into Europe and settled in the three southern peninsulas, gradually spreading northwards over the Alps and extending eventually up. to the Baltic. As they gradually spread upwards under the influence of their environment (and in environment, I of course include food), they grew less dark, those of them who settled permanently along the axis of the Alps tending to have shorter skulls, whilst those who had passed onwards earliest became the most blonde and tallest people in the world. On the other hand I revolted from Sergi's doctrine of a Mediterranean Race which comprised Hamites and Semites as. well as those speaking an Aryan language. I pointed out that the evidence for the dark races of Greece, Italy and Spain having always spoken an Aryan language is very weighty, and that Sergi has simply assumed that similarity of physical type means identity of race. I maintained that the similarity between the populations of Greece, Italy, Spain and parts of France, and the British Isles to the Hamites. and Semites is simply due to convergence of physical types under similar conditions, instancing various analogies from the lower animals.

As the discussion had of necessity to deal with questions of race, I examined in my address (p. 2), the criteria by which anthropologists distinguish one race from another. These are (1) pigmentation (colour of the skin, hair and eyes); (2) the shape of the skull and other osteological characteristics; (3) the systern of descent.. I added that formerly language had been included in the tests of race, but when it was pointed out that the negroes of Jamaica speak English, those of Louisiana French, it was thenceforward assumed that one race can embrace the language of another with the greatest ease. Yet it may turn out after all that language was. too hastily expelled from the criteria of race. On the other hand, further investigations may show that too implicit faith has been placed in the three criteria of Cranial Characteristics, Pigmentation, and the Law of Succession. It will. 
be thus seen that I have not substituted language as a criterion of race for cranial and other osteological characteristics, pigmentation, or law of succession.

I then examined the value of these three criteria in general use, and I was forced to the conclusion that osteological differences could not be implicitly relied on and might in some cases prove to be merely foundations of sand, because it is certain such variations take place within very short periods, not only in the case of the lower animals, as in the horse family, but in Man himself. Pigmentation also is not an infallible criterion, for there is a steady tendency in the case of the lower animals to change in colour from latitude to latitude, whilst in the case of Man a steady shading off in colour from dark to blonde may be traced from the Equator to the Baltic. Unless then we postulate that Man is entirely free from the natural laws which condition the osteology and pigmentation of other animals, we must admit that neither bone nor colour differences can be regarded as crucial criteria. The test of descent through males broke down completely, as descent through females can be proved for those who never spoke any but an Aryan language. Finally, I was led to the conclusion that language, when once we realise the laws which govern its borrowing by one race from another, may be taken as a test of race and really as the surest when dealt with broadly and over wide areas and not merely in the way of guess-work etymologies in the case of isolated words.

I had constantly been asked: "How do you explain the fact that in Ireland and in Britain, countries lying so far north, you have the dark Mediterranean race?" To this I invariably reply: You have a dark race, but very different from the dark race as found in the southern peninsulas. The hair is certainly very dark, yet it is not the blue-black hair of the south, whilst the skin is beautifully fair, especially in the west of Ireland, where there has been no admixture, and the eyes are regularly blue. You have in this dark type a transition stage between the melanochrous type of the same race in Spain, Italy, and Greece, with its olive skin, blue-black hair and black eyes, and the tall blonde Scandinavian, where the change in pigmentation is now far advanced, the hair as well as the eyes have become of light hue. I give as a reason for this retardation of change in Ireland the influence of the Gulf Stream, and I point out that especially in the west of Ireland the flora comes close to that of the Spanish Peninsula. For instance, the fine Mediterranean heath grows round the west coast of Ireland from Clifden southwards, whilst there are also some coincidences between the fauna of both regions. As the dark type in Ireland so frequently shows blue eyes, I was led to conclude that the pigmentation of the eye is less stable than that of the hair.

Let us now 'turn to theDanish results. These show all kinds of pigmentation both in hair and eyes, but with some very important limitations. (1) A very large proportion have blonde hair and blue eyes. (2) A very large number have dark hair and dark eyes. (3) A considerable number have dark hair but blue eyes (just as in Ireland); whilst (4) A few, but very few, have blonde hair and dark eyes, a phenomenon also known in Ireland, but very rare there likewise. 
My doctrine of the instability of eye colour has recently received remarkable confirmation. Dr. William Wright in his Hunterian Lectures (III, 7) writes: "The effect of sunlight in darkening the skin is well known. As to eye colour, my friend Mr. J. V. Hodgson, biologist to the Scott Antarctic Expedition, informed me that, as a result of living under such unusual conditions, the eyes of the members of the expedition became so blue as to occasion remark on their return to New Zealand, and also on their arrival home in this country. Colour, therefore, like the cephalic index and stature, is also prone to change, and in itself is not deserving of implicit trust." But though the pigmentation of the eye can be quickly modified in the individual under new conditions, the race would probably have to live under the like conditions for a very long period before such blueness would become a fixed racial trait.

It will be seen that (1) my views respecting the short-skulled Alpine race have been endorsed by eminent craniologists, and by the conclusions drawn from the Danish Anthropometric Survey, and (2) that my theory of the origin of the blonde northern race, and of the complexion and light coloured eyes of the north Europeans has likewise been confirmed by the same survey and by the evidence derived from the Antarctic expedition, so far as that goes. Thus within a short time since it was first propounded, my theory of the origin of the blonde Aryans has been corroborated by various kinds of evidence, and has also been endorsed by leading anatomists.

Some years ago Professor R. M. Burrows in his Discoveries in Crete (p. 194) criticised my doctrine that the dark population of Greece and Italy had from the outset never spoken any save an Aryan language. But since my reply to him (Who were the Romans? p. 35, sqq.) neither he nor anyone else has returned to the attack, whilst Mr. Bernard Houghton, though cavilling at the doctrine, does not attempt to bring any arguments against it. On the other hand he. has made his most vigorous onslaught upon my theory of the origin of the blonde race of Upper Europe. He describes his paper as an attempt to show that the arguments used by me "rest on foundations of quicksand and that the inferences do not really arise from the facts adduced." "The fundamental error" (in my position) says he, "consists in an assertion of the essential fluidity of head-form and suchlike physical characteristics and in their derivation from climatic and other surroundings, in contrast with an alleged permanence over a given area of the language originally spoken there. He predicates likewise a similar local permanence of idiosyncrasy, polity, and social and religious ideas. The central and dominant feature of the first part of his address consists in an ascription to local influences of those physical traits of mankind which have hitherto, by all competent investigators, been referred to racial causes, that is, to heredity."

Let me at once point out that while $I$ do ascribe great importance to the influence of environment as a factor in the formation of races, $I$, hold also very strongly the doctrine of heredity -in fact, much too strongly for Mr. Houghton's fancy when he has to deal with my doctrine of the great, if not the leading part, played 
by heredity in our own chief social problems. ${ }^{1}$ But the grand riddle of the true relation between heredity and environment has yet to find an CEdipus to solve it.

Let us now turn to the arguments by which Mr. Houghton thinks that he has demolished my position. I need hardly say that his case depends wholly on the assumption that Man is absolutely free from the natural laws which condition the osteology and pigmentation of other animals. This he thinks was settled once for all when Sir E. Ray Lankester described Man as "Nature's insurgent son." "Once man had discovered fire, clothed himself with the skins of beasts, and built. himself a house, he had once for all freed himself from the laws that govern the rest of Nature." This of course is a fair statement of the views put forward by Sir E. Ray Lankester in his Romanes Lecture at Oxford in 1905, and since republished in his book entitled The Kingdom of Man. On p. 22 of that work he writes: "In the Lower Miocene there seems to have been a sudden development of brain size not merely in man, but in other animals. Other great mammals of the earlier Tertiary period, such as the rhinoceros, were in the same case." He proceeds (p. 24): "It appears that the increased bulk of cerebral substance means increased educability - an increased power of storing up individual experience, which tends to take the place of the inherited mechanism with which it is often in antagonism. The power of profiting by individual experience, in fact educability, in conditions of close competition when other conditions are equal, must be an immense. advantage to its possessor. It seems that we have to imagine that the adaptation of a mammalian form to the various conditions of life had in Miocene times reached a point when further alterations and elaboration of the various types which we. know then existed, could lead to no advantage.

"The variations present for election in the struggle for existence presented no advantage-the fittest had practically been reached and was destined to survive with little change. Assuming such a relative lull in the development of mere mechanical form, it is obvious that the opportunity of those individuals with the most educable brain to defeat their competitors would arise. No marked improvement in the instrument being possible, the survival would fall to those who possessed most skill in the use of the instrument and in successive generations the bigger and more educable brains would survive and mate, and thus bigger and bigger brains would be produced. It would not be difficult, though not perhaps profitable, to imagine the conditions which have favoured the continuation of this process to a far greater length in the Simian line of the pedigree than in other mammalian groups. The result is that the creature called Man emerged with an educable brain of some five or six times the bulk (in proportion to his size and weight) of that of any other surviving Simian." On p. 25 he writes: "The mental qualities which had developed in man, though traceable in a vague and rudimentary condition in some of his animal associates are of such an unprecedented power, and so far dominate everything else in his activities as a living.

${ }^{1}$ See my reply in Science Progress, July, 1910, pp. 143-6. 
organism, that they have to a very large extent, if not entirely, cut him off from the general operations of that process of Natural Selection and survival of the fittest which up to their appearance had been the law of the living world. . . . If for the purpose of analysis, as it were, we extract Man from the rest of Nature, of which he is truly a product and a part, then we may say that Man is Nature's rebel. Where Nature says 'die,' Man says 'I will live.' According to the law previously in universal operation, Man should have been limited in geographical area, killed by extremes of cold or of heat, subject to starvation, if one kind of diet were unattainable, should have been unable to increase and multiply just as are his animal relatives, without losing his specific structure, and acquiring new physical characteristics according to the requirements of the new conditions into which he strayed, and should have perished except on the condition of his becoming a new morphological 'species.' But Man's wits and his will have enabled him to cross rivers and oceans by rafts and boats, to clothe himself against cold, to shelter himself from heat and rain, to prepare an endless variety of food by fire, and to increase and multiply as no other animal, without change of form, without submitting to the terrible axe of selection wielded by ruthless Nature over all other living things on the globe." Again we read (p. 27): "In spite of the frequent assertion to the contrary, it seems that neither the more ancient wars of mankind for conquest and migration, nor the present and future wars for commercial privilege, have any real equivalents to the simple removal by death of the unfit and the survival and the reproduction of the fit, which we know as Natural Selection."

Yet after all these bold statements of the freedom of Man from the operation of Natural Selection, Sir E. Ray Lankester in a footnote, p. 28, says : "It would be an error to maintain that the process of Natural Selection is entirely in abeyance in regard to Man." In an interesting book, The Present Evolution of Man, Dr. Archdall Reid has shown that in regard to zymotic diseases and also in the use of dangerous drugs, such as alcohol and opium, there is first of all the acquirement of immunity by powerful races of men, through the survival among them of those strains tolerant of the disease or of the drug, and secondly, the introduction of those diseases and drugs by the powerful immune race, in its migrations, to races not previously exposed either to the disease or to the drug, and the consequent destruction of the invaded race. The survival of the fittest in these cases is the survival of the tolerant and eventually of the immune.

This is not the place to point out the series of assumptions made by Sir E. Ray Lankester in his brilliant description (chiefly imaginative) which he drew for his Oxford audience of the emergence of Man from the stage when like all other animals he was under the law of Natural Selection. His own admission contained in his footnote just cited, that Natural Selection is still at work, and that too in most potent forms, is sufficient to demonstrate the untenable nature of the position which he took up in his Romanes Lecture. Yet it is on these dogmatic assertions of Sir E. Ray Lankester that Mr. Houghton bases his criticisms of my doctrines. 
Yet the assumption that Man can go into climes very different from those in which his race has long dwelt without any morphological change, is in direct conflict with many known facts. The American of New England with his hatchet face and his thin scraggy beard differs essentially in his type from his English ancestor, whilst the Boer of South Africa shows no less variation from the type of his Dutch progenitors. The instance just cited of the influence of the Antarctic environment on the colour of the eyes is in itself sufficient to demonstrate the falseness of his assumptions. Mr. Torday and Mr. Joyce have furnished me with a still more striking example from their book on the Congo (shortly to be published). It relates to the pygmies who live in the forests of that region, and are known as Ba Twa. The Bu Shongo, who found the Ba Twa in possession, hold them in superstitious awe, regarding them as spirits born from trees. In some cases bands of these pygmies have been induced to leave the forest, to settle in villages and to practise agriculture.

In such cases they are regarded by the Bu Shongo as becoming more human, but no intermarriage ever seems to take place between Bu Shongo and Ba Twa. Mr. Torday visited two of these villages of settled Ba Twa. The Bu Shongo told him that it is only three generations since these Ba Twa left the forest. He noted that the stature of the inhabitants was considerably above that of the nomad $\mathrm{Ba}$ Twa, though it did not equal that of their Bu Shongo neighbours. "As the possibility of intermarriage seems quite out of the question, it seems necessary to conclude that the short stature of the pygmies is in some way due to the dwarfing effect of forest life or to the Natural Selection exercised by environment."

Mr. Claude White in his recent book, Sikhim and Bhutan, writes: "The people of the West (of Bhutan) are for the most part of Tibetan origin, and came into the country centuries ago. They are of the same original stock as the Bhutias in Sikhim, but have developed in Bhutan into a magnificent race of men physically. Why there should be this marked contrast, I cannot say. It may be due to the difference in climate; but there is no comparison between the two, although the Sikhim Bhutia is a strong sturdy fellow in his own way." My friend, Mr. J. D. Anderson, I.C.S., Reader in Bengali to the University of Cambridge, has. pointed out to me that the greater stature of the Khasis of Assam, who dwell in the midst of Tibeto-Burman tribes, compared with that of their Burmese cousins, the Monds, is to be attributed to their environment in Assam, where they continue to speak their own language, though assimilated in physical type to the Assamese tribes around. In passing I may point out that we have in their case an admirable example of the great value of language as a criterion of race. Were it not that these folk have preserved their language, though settled in the midst of an alien race, to which they have physically been assimilated, it would have been assumed that they were of the same stock as their neighbours.

A good many years ago the Indian Government, acting upon strictly Weismannic principles, proposed to plant colonies of Ghoorkas from Nepal in the plains of India in order that we might breed a supply of these admirable soldiers 
for ourselves and not be dependent on the Maharajah of Nepal. A distinguished officer of a Ghoorka regiment on being consulted, very wisely pointed out that if the project was carried into effect, within a few generations the descendants of the Ghoorka colonists would be as worthless for military purposes as the Hindu of the plains. The history of race after race that has entered India and become master of its feeble folk repeats the same sad story of a splendid physique and morale corrupted and moribund within a few generations.

It is a pity that Mr. Houghton did not acquaint himself with the footnote which I. have cited, in which his master admits the activity of Natural Selection at the present moment in the human family. But Mr. Houghton himself makes an admission which cuts away the ground from under his feet. He writes: "When he (Ridgeway) goes on to say that the skins of mankind tend to get lighter in gradations from the Equator to the Pole, he stands on firmer ground. Undoubtedly the skin of races long inhabiting the tropics evinces a deeper pigmentation than in those residing in more temperate regions. The reason for this is obvious: although histologists are not agreed as to the cytological facts of pigmentation, it undoubtedly tends, just as do freckles, to protect the outer layers from the actinic rays of the sun." Yet when he comes to deal with my theory that the white skin of the blonde race of Northern Europe is due also to climatic causes, analogous to those which have produced the white hares and white bears, and makes the ptarmigan turn white in winter, he makes merry over my ignorance and stupidity, declaring that such a view " implies a singular inability to grasp the relevant facts of the case or to frame inductions upon them. The whiteness of animals inhabiting northern regions, whether perennial or seasonal, is a very simple case of adaptive colouring first demonstrated by Dr. A. Russell Wallace and now obvious to the merest tyro in biology. Who will assert that blondeness of hair in any way favours a race in a northern habitat. Does Professor Ridgeway mean to assert that in winter our ancestors pursued game or eluded their foes in a state of nudity?"

"Words," says Hobbes, "are the counters of wise men, but the money of fools." Mr. Houghton like many others of his school catches up terms such as "Protective Colouring, Mimicry of Mutation," and believes that by constantly repeating them in parrot fashion he is enunciating irrefragable truths of science. But what is "adaptive colouring"? Adaptive is a relative term. To what is the colour adapted? Of course to the environment in which the animal lives. Accordingly adaptivity is simply one element in my larger doctrine of environment, as is also the case with protective colouring, mimicry, and mutation. But it by no means follows that white is only to protect the animal from his animal foes or to render it easier for it to stalk its prey. I have made no such assumption respecting either the whiteness of arctic animals or the blondeness of the northern race. I only argue from the analogy of the dark colour of the negro in the tropics, which Mr. Houghton himself admits to be protective, not against animal foes, but against "the actinic rays of the sun." In other words, it is a case of "adaptive colouring," as he might have seen, had he understood the use. 
of that term which he rattles off so glibly. He is evidently not aware that the leading biologists now explain the white colour of arctic animals, not as a protection against living foes, but because white is the best colour for keeping in the heat of the body. The blondeness of the northern race may have therefore a real protective value, as has the blackness of the negro by Mr. Houghton's own admission.

But this is not mere theory. When the Nares and Markham Arctic expedition was being organised, it was stated in the press that in selecting men for the crews, preference was given to the blondes, because the experience of whalers had shown that fair-complexioned men stood the rigours of the arctic winter better than those of a melanochrous hue. Conversely there is a large body of evidence to show that in West Africa, the Solomon Islands and other tropical regions, men of blonde complexion suffer far more from climate than those of a dark complexion. The change in the hue of the eyes under antarctic conditions cited above, clearly proves a connection between light colour and antarctic or arctic conditions, which is not for the purpose of protection against living foes. This "adaptive colouring " is certainly not to protect inan from the penguins and other birds, nor yet to enable men to capture these birds more easily, but it has probably a far deeper protective significance.

Now as Mr. Houghton admits that the action of environment affects the pigmentation of the skin in tropical and subtropical countries, but on the other hand denies it for northern regions, he is bound to show at what point, let us say between the Sudan and Northern Europe, this natural law ceases to be operative. Does it suddenly cease to act amongst the Nilotic tribes, or is it in Egypt that he draws his line, or is it the Mediterranean which says, "so far and no farther shall atmosphere and other causes act upon the skin." No scientific man who admits that the skin of certain races is affected by their environment, would dream of excluding the rest of mankind from similar action; even though Sir E. Ray Lankester may state dogmatically that man can advance from the Equator to the Arctic circle without undergoing any morphological change. No man of science when once the facts are presented would believe this for a moment.

It is admitted by Mr. Houghton as well as by every one else that the pigmentation of the negro acts as a protection against tropical light. At what point on the globe do the inventions of man, by which, according to Sir E. Ray Lankester, he has freed himself from the laws that condition the rest of nature, cease to act. At what point as we go north will Sir E. Ray Lankester assert, "Here man's clothes and houses and fire shut him off from Nature's laws?" So too when we come to Europe. Even in these climates where we northerners dwell, arrayed in warm vesture against the assaults of the Boreas, our faces and hands are exposed to the direct action of the atmosphere, and the air must circulate round us, unless we be clad in plaster. Yet our remote ancestors in their slow struggle against nature had but very scanty raiment. The action of the atmosphere suffered but little check from a skin thrown over the shoulders to keep off the pelting rain 
But even if clothes could check climatic action on the skin, there are other ways in which environment is constantly acting on man, as it does on the rest of the mammals. Man has to breathe, and therefore, unless he were able to rid himself of his respiratory organs, as he advanced northward, the chemical and physical processes of his body must be influenced by the nature of the air inhaled by his lungs. No sane person will doubt that the atmosphere of one region differs from that of another. If it does not, why do we send those who are suffering from pulmonary phthisis to high altitudes, or to dry climates, such as Australia or the Cape? Again, man, especially primitive man, depends for subsistence on the food produced by the locality in which he lives, or in that from which he draws his supplies. But foods differ according to the nature of the soil and climate. Accordingly, men in each locality must be modified by the character of the food produced in that area, when it is assimilated by the chemical processes of the body, unless they are provided with tin or copper linings throughout the entire length of the alimentary canal.

I have pointed out that altitude acts like latitude. This Mr. Houghton disputes, on the ground that the Pigmentation Survey of Scotland shows blondeness to be predominant in the valleys and dark hair in the mountains, and because in the Himalayas and elsewhere, melanochrous people are to be found sporadically at the present time. But the Scottish example is at once explained by the settlement of fair-haired folk from Northern Europe well within historical times, who drove into the hills the weaker aboriginal dark race.

He is careful not to deny that the dark tribes found occasionally in mountain areas in India and elsewhere have only taken refuge there in recent times.

The action of the atmosphere upon the skin can be observed in our own islands. The delicate pink complexion characteristic of Ireland and the West of England is in striking contrast to the pasty complexion of the women of the East of England, whether blonde or brunette. I know a case where a Jewish girl reared in Cork grew up with the typical Irish complexion instead of the hereditary tint of her parents.

I have hitherto spoken only of the action of atmosphere on the skin. There is an equally great probability that the various types of hair-the wool of the Negro with its quadrangular section, the straight hair of the Mongolian with its oval section, and the various forms of European hair are due to climatic conditions. It is certainly a curious fact recorded by Azara that the horses and the cattle in Paraguay, where of course these animals have only been introduced from Europe within the last three centuries, have a singular tendency to grow short curly hair like that of the negro. This may be regarded as a clear example of the action of environment upon hair. If this is so in the case of the large mammals there is no reason why a like cause may not have acted upon the hair of the negroes, whose natural habitat is a climate not unlike that of Paraguay. The action of the atmosphere on hair even in our own islands is very noticeable. It is not improbable that the curly hair so much more frequently seen in Irish villages than in English 
is due to the difference in the atmosphere, just as the pink complexion mentioned already.

In my Origin and Influence of the Thoroughbred Horse I was able to show that there is a very distinct relation between the coat-colours of horses, bay, brown, chestnut, black, grey, white dun, and their internal qualities. We need not therefore be surprised, if before long the physiologists will be able to demonstrate the existence of distinctive differences between the various races of men, such as hitherto have not been dreamed of. One very important discovery has already been made in this direction. My friend Sir H. H. Risley, K.C.I.E., has lately called my attention to some very interesting facts recently published respecting the difference between the arterial pressure and blood constituents of Bengalis and those of Europeans. The arterial pressure in the case of the former is much lower than the European standard, whilst the percentage of blood corpuscles is also much less. At present it would be premature to say dogmatically that this is the result of environment, but as the pigmentation and the characteristic hair of the Negro are admittedly concomitants of life in the torrid zone, and as the horses and cattle introduced into Paraguay show an analogous phenomenon, we need not be surprised if it should turn out that in other physiological characteristics the negro not only differs widely from the various types of Europeans and Asiatics, but also that the various peoples of Europe and Asia differ widely from each other in similar respects. Their differencès in external characteristics, blondeness, or dark complexion, and the like, may be found to have corresponding internal qualities as in the case of horses. Further researches on this particular line of investigation are now being carried out in India, and let us hope that some of those brilliant men who are engaged in Africa in the study of sleeping sickness may be able to devote some of their attention to this very important field of Anthropology.

In our new President, Sir H. H. Risley, we have the founder and organiser of the great Ethnographical Survey of India. We may rest assured that under his headship the Royal Anthropological Institute will be able to exercise on everything that appertains to Man a more stimulating influence than ever before in its history.

As this paper is just being printed off, the Report of the Immigration Commission of the United States Government, "On the changes in bodily form of descendants of Immigrants," has reached me. The results already obtained by Professor Boaz corroborate most strongly the views put forward by me at York (1906) and at Dublin (1908). "The head form undergoes far-reaching changes due to the transfer of the races of Europe to American soil. The east European Hebrew, who has a very round head, becomes more long-headed; the south Italian, who in Italy has an exceedingly long head, becomes more short-headed; so that both approach a uniform type in this country, so far as the roundness of the head is concerned . . . we are compelled to conclude that when these features of the body change, the whole bodily and mental make-up of the immigrants may change." 